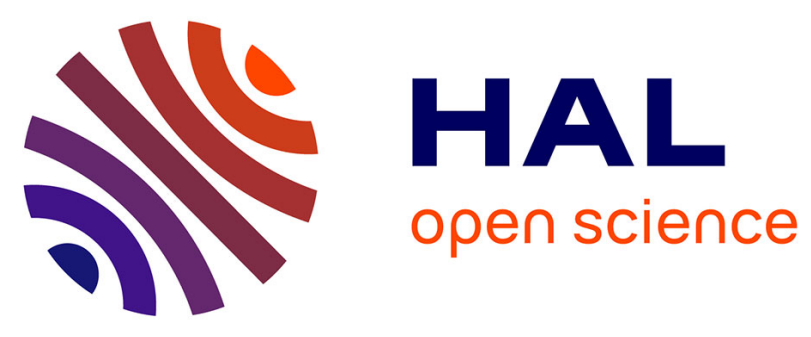

\title{
Iron Tissue Storage and Hemoglobin Levels of Deficient Rats Repleted with Iron Bound to the Caseinophosphopeptide 1-25 of $\beta$-Casein
}

Nabil Aît-Oukhatar, Said Bouhallab, Pierre Arhan, Jean-Louis Maubois, Michel Drosdowsky, Dominique Bouglé

\section{To cite this version:}

Nabil Aît-Oukhatar, Said Bouhallab, Pierre Arhan, Jean-Louis Maubois, Michel Drosdowsky, et al.. Iron Tissue Storage and Hemoglobin Levels of Deficient Rats Repleted with Iron Bound to the Caseinophosphopeptide 1-25 of $\beta$-Casein. Journal of Agricultural and Food Chemistry, 1999, 47 (7), pp.2786-2790. 10.1021/jf981018k . hal-01559711

\section{HAL Id: hal-01559711 \\ https://hal.science/hal-01559711}

Submitted on 10 Jul 2017

HAL is a multi-disciplinary open access archive for the deposit and dissemination of scientific research documents, whether they are published or not. The documents may come from teaching and research institutions in France or abroad, or from public or private research centers.
L'archive ouverte pluridisciplinaire HAL, est destinée au dépôt et à la diffusion de documents scientifiques de niveau recherche, publiés ou non, émanant des établissements d'enseignement et de recherche français ou étrangers, des laboratoires publics ou privés.

\section{다(1)(2)}

Distributed under a Creative Commons Attribution - ShareAlikel 4.0 International 


\title{
Iron Tissue Storage and Hemoglobin Levels of Deficient Rats Repleted with Iron Bound to the Caseinophosphopeptide 1-25 of $\beta$-Casein
}

\author{
Nabil Aît-oukhatar, ${ }^{\dagger}$ Saïd Bouhallab, ${ }^{\ddagger}$ Pierre Arhan, ${ }^{\dagger} \mathrm{J}$ ean-Louis Maubois, ${ }^{\ddagger}$ \\ Michel Drosdowsky," and Dominique Bouglé*,t,§
}

\begin{abstract}
Laboratoire de Physiologie Digestive et Nutritionnelle, CHU de Caen, F 14033 Caen, France; Laboratoire de Technologie Laitière, INRA, Rennes, France; and Laboratoire de Biochimie and Service de Pédiatrie A, CHU de Caen, F14033 Caen, France
\end{abstract}

\begin{abstract}
Caseinophosphopeptides (CPP) issued from enzyme digestion of caseins bind cations and keep them soluble in the digestive tract. They could be used as ligands to improve iron (Fe) bioavailability. Fe-deficient young rats were repleted with $\mathrm{Fe}(40$ or $200 \mathrm{mg} / \mathrm{kg}$ of diet) bound either to the $\beta$-CN (1-25) of $\beta$-casein or to whole $\beta$-casein or as $\mathrm{FeSO}_{4}$. A control pair-fed group was given $200 \mathrm{mg}$ of $\mathrm{Fe}\left(\mathrm{FeSO}_{4}\right) / \mathrm{kg}$ of diet for 6 weeks. After repletion, hemoglobin concentration of the control group was reached only by the $\beta$-CN (1-25) animals fed $200 \mathrm{mg}$ of $\mathrm{Fe} / \mathrm{kg} ; \beta$-CN (1-25) bound $\mathrm{Fe}(40$ and $200 \mathrm{mg}$ ) produced higher $\mathrm{Fe}$ liver and spleen stores than $\mathrm{FeSO}_{4}$. Binding $\mathrm{Fe}$ to the whole, nonhydrolyzed $\beta$-casein gave results intermediate between the other experimental groups. Binding Fe to phosphoserine residues of low molecular weight CPP improved its ability to cure anemia and to restore iron tissue stores, as compared to Fe bound to the whole casein and to inorganic salts.
\end{abstract}

Keywords: Iron; bi oavailability; tissuestorage; hemogl obin; casein phosphopeptide; milk proteins; rat

\section{INTRODUCTION}

Iron (Fe) absorption is usually poor and is influenced by interactions with other food components: Proteins can enhance or decrease Fe absorption depending on their origin; soy and other vegetal proteins usually reduce $F$ e absorption, even if phytates are removed from vegetal proteins, although there are some conflicting reports (Cook and Monsen, 1976; Hurrell et al., 1989, 1992; Thompson and Erdman, 1984; Wapnir, 1990). Animal foods such as beef, pork, chicken, and fish are enhancing factors due to their content in cysteine (Cook and Monsen, 1976; Martinez-Torres et al., 1981). Hemebound iron is soluble at the alkaline $\mathrm{pH}$ of proximal bowel and is absorbed by a specific pathway, which results in a high absorption rate (Beard, 1996). Eggs, milk, and milk products such as cheese are assumed to be inhibitors of non-heme Fe absorption (Beard, 1996; Cook and Monsen, 1976; Hurrell et al., 1988, 1989; Wapnir, 1990); their phosphoproteins strongly bind transition metals by ionic interactions with their phosphoseryl residues (Brulé et al., 1979; Demott and Dincer, 1976; Hegenauer et al., 1979; West, 1986); therefore, they could release Fe too far down the intestine for efficient absorption (Miller and Berner, 1989; West, 1986). Binding Fe to low molecular weight,

* Address correspondence to this author at Service de Pédiatrie A, CHU Clémenceau, Avenue G Clémenceau, F 14033 Caen Cedex, France (telephone 332 31272594; fax 332 31743529).

† Laboratoire de Physiologie Digestive et Nutritionnelle.

* Laboratoire de Technologie Laitière.

"Laboratoire de Biochimie.

$\S$ Service de Pédiatrie A. soluble peptides could overcome this pitfall and favor its absorption.

Caseinophosphopeptides (CPP) are yielded by in vitro (J uillerat et al., 1989) or in vivo (Kasai et al., 1995; Meisel and Frister, 1989; Naito et al., 1972) enzyme cleavage of casein and are considered to be stable to further proteolysis by digestive enzymes (Kasai et al., 1995). The 25 amino acid CPP issued from tryptic hydrolysis of $\beta$-casein $[\beta$-CN (1-25)] contains four of the five phosphoserine residues of the native protein ( uillerat et al., 1989; Manson and Annan, 1971; West, 1986):

H-Arg-Glu-Leu-Glu-Glu 5 -Leu-Asn-Val-Pro-

Gly $_{10}$-Glu-Ile-Val-Glu-Ser $\mathrm{P}_{15}$-Leu-SerP-SerPSerP-Glu 20 -Glu-Ser-Ile-Thr-ArgOH 25

CPP have a high capacity to bind divalent cations such as calcium, Fe, zinc, and copper and keep them soluble at luminal pH (Berrocal et al., 1989; Galdi and Valencia, 1988; Meisel and Frister, 1989; Sato et al., 1991); affinity of caseins is 50-100-fold higher for Fe than for calcium or magnesium (Brulé and Fauquant, 1982).

Binding $\mathrm{Fe}$ to $\beta$ - $\mathrm{CN}$ (1-25) enhances its digestive absorption and prevents the inhibitory effect of calcium (Pérès et al., 1997, 1998).

In the present study it was assumed that binding $\mathrm{Fe}$ to this low molecular weight phosphopeptide could improve al so its ability to restore hemogl obin levels and tissue storage of the Fe-deficient animal as compared to a free $\mathrm{Fe}$ salt $\left(\mathrm{FeSO}_{4}\right)$ or to $\mathrm{Fe}$ bound to the large intact $\beta$-casein. Two doses of $\mathrm{Fe}$ were used: the lower one ( $40 \mathrm{mg} / \mathrm{kg}$ of diet) is based on the nutrient requirements for rats (National Research Council, 1995); the higher one (200 mg/kg of diet) intends to mimic the amount of Fe supplied by fortified products. 
Table 1. Composition of the Diet ${ }^{\mathrm{a}}$

\begin{tabular}{llll}
\hline \multicolumn{1}{c}{ nutrient } & \multicolumn{2}{c}{ nutrient } \\
\hline protein (\%) & 20 & minerals and vitamins (\%) & 5.5 \\
lipids (\%) & 4.4 & iron (mg/kg) & $5-40,200$ \\
carbohydrates (\%) & 56.4 & moisture (\%) & 9.7 \\
cellulose (\%) & 4.3 & &
\end{tabular}

a Diet deprived of protein (UAR Aprotéique) to which casein or casein $+\beta$-casein derived peptides were added to a final level of $20 \%$. Components of UAR Aprotéique: proteins, $0 \%$; glucose + starch, 80\%; cellulose, 6\%; lipids, 6\%; (minerals) P, $7.75 \mathrm{~g} / \mathrm{kg}$; Ca, 10 g/kg; K, 6 g/kg; Na, 4 g/kg; Mg, 1 g/kg; Mn, 80 mg/kg; Zn, 45 $\mathrm{mg} / \mathrm{kg} ; \mathrm{Cu}, 12.5 \mathrm{mg} / \mathrm{kg}$; (vitamins) A, $19800 \mathrm{UI} / \mathrm{kg} ; \mathrm{D}, 2500 \mathrm{UI} / \mathrm{kg}$; B1, $20 \mathrm{mg} / \mathrm{kg} ; \mathrm{B} 2,15 \mathrm{mg} / \mathrm{kg} ; \mathrm{B} 6,10 \mathrm{mg} / \mathrm{kg} ; \mathrm{E}, 170 \mathrm{mg} / \mathrm{kg} ; \mathrm{K}, 40$ $\mathrm{mg} / \mathrm{kg}$; PP, $100 \mathrm{mg} / \mathrm{kg}$; biotin, $0.3 \mathrm{mg} / \mathrm{kg}$; folic acid, $5 \mathrm{mg} / \mathrm{kg}$.

\section{MATERIALS AND METHODS}

Protein and Peptide Source. $\beta$-Casein was isolated from industrially made sodium caseinate (Armor Protéines, StBrice-en Coglés, France) using its solubility at pH 4.5 at $4{ }^{\circ} \mathrm{C}$ followed by ion exchange chromatography (Baumy and Brulé, 1988; Bouhallab et al., 1991). The $\beta$-CN (1-25) was prepared using a tryptic hydrolysis of $\beta$-casein (Brulé et al., 1979).

$\beta$-CN (1-25) was then incubated at a concentration of 12.5 $\mathrm{mg} / \mathrm{mL}\left(7 \times 10^{-6} \mathrm{~mol} / \mathrm{L}\right)$ with 10 -fold excess of $\mathrm{FeCl}_{2}$ solution $\left(4 \times 10^{-2} \mathrm{~mol} / \mathrm{L}, \mathrm{pH} 5.3\right)$ during $30 \mathrm{~min}$ at $25^{\circ} \mathrm{C}$ (Milli-Q system, Millipore). The preparation was dialyzed during $24 \mathrm{~h}$ at $4{ }^{\circ} \mathrm{C}$ to remove unbound $\mathrm{Fe}$, using dialysis bags with a cutoff of $1000 \mathrm{Da}$. Binding Fe to the $\beta$-casein was performed in the same way, but concentrations of $\beta$-casein and of $\mathrm{FeCl}_{2}$ were $5.2 \times 10^{-4} \mathrm{~mol} / \mathrm{L}(12.5 \mathrm{mg} / \mathrm{mL})$ and $2.6 \times 10^{-3} \mathrm{~mol} / \mathrm{L}$, respectively. The amount of Fe complexed to $\beta$-CN (1-25) or to $\beta$-casein was determined by atomic absorption spectrometry (Varian; model AA 1275). A dialysis control without $\beta$-CN (125) or protein was performed.

Four moles of Fe were bound per mole of $\beta$-CN $(1-25)$ and $5 \mathrm{~mol}$ of $\mathrm{Fe}$ per mole of the native $\beta$ casein. Fe is bound to phosphoserine residues in a ferric form (E mery, 1992).

Experimental Design. Weaning male Sprague Dawley rats (issued from the farm of the University of Caen), 23 days old, weighing 50-60 g, were housed individually in plastic and stainless steel wire bottom metabolic cages. They were divided into six groups of eight rats. Five groups were fed an Fedeficient diet $(<5 \mathrm{mg}$ of $\mathrm{Fe} / \mathrm{kg}$ ) containing $20 \%$ protein as casein (UAR, Villemoisson-sur-Orge, France) for 4 weeks. Rats had free access to diet and distilled water. At the end of this depletion period, these five deficient experimental groups were fed the same Fe-deficient diet to which Fe had been added at respective concentrations of 40 and $200 \mathrm{mg} / \mathrm{kg}$. Fe sources were $\mathrm{Fe}^{2+} \mathrm{SO}_{4}$ [groups ( $\mathrm{FeSO}_{4} 40 \mathrm{mg}$ ) and $\left(\mathrm{FeSO}_{4} 200 \mathrm{mg}\right)$ ], $\mathrm{Fe}$ bound to $\beta$-CN (1-25) [groups $\beta$-CN (1-25) $40 \mathrm{mg}$ and $\beta$-CN $(1-25)$ $200 \mathrm{mg}$, and $\mathrm{Fe}$ bound to $\beta$-casein (group Cas-Fe $200 \mathrm{mg}$ ). During the 2 weeks of the repletion period the five groups had free access to diet and distilled water.

A control group (pair-fed) was pair-fed to the mean intakes of $\mathrm{Fe}$-deficient groups with the standard diet $(20 \%$ protein as casein; $200 \mathrm{mg}$ of $\mathrm{Fe} / \mathrm{kg}$ of diet as $\mathrm{FeSO}_{4} \cdot 7 \mathrm{H}_{2} \mathrm{O}$ ) for 6 weeks. The detailed composition of the diet is given in Table 1: casein or casein $+\beta$-casein derived peptides were added to a final level of $20 \%$ to a diet deprived of protein (UAR Aprotéique). Animals were weighed upon arrival in the laboratory and weekly thereafter.

After 4 weeks, blood was drawn for a blood cell count on a Coulter Counter S890. Plasma Fe was measured, but data were discarded due to an unpredictable degree of hemolysis that occurred during drawing blood.

At the end of the experiment, animals (65 days old) were killed by an overdose of pentobarbital; blood was drawn for another blood cell count, and liver and spleen were excised, weighed, and frozen; before analysis, the organs were dried at $90^{\circ} \mathrm{C}$, ground, and digested by nitric acid (ultrapure nitric acid, Merck) in a microwave oven (Microdigest A 301, Prolabo, France).
Fe concentration was measured by atomic absorption spectrometry (Perkin-EImer 3030).

Bovine liver standard (National Bureau of Standards, Washington, DC, Standard Reference Material NIST 1577B) was analyzed to evaluate the methodological accuracy of the laboratory method. Certified concentration was (mean \pm 1 SD) $184 \pm 15 \mu \mathrm{g} / \mathrm{g}$; Iaboratory value was $(\mathrm{n}=13) 190 \pm 6 \mu \mathrm{g} / \mathrm{g}$. The run to run coefficient of variation was $1.29 \%(n=30)$.

Statistical Analysis. Data are expressed as means and standard errors of the mean (SEM). The experimental data were analyzed by two-way ANOVA followed by Fisher's exact tests on statView SE + Graphics, Abacus Concept, Inc.

ANOVA with repeated measures was used to assess the changes in hemoglobin levels between the beginning and the end of repletion.

Comparisons were made within the 4 groups fed $200 \mathrm{mg}$ of $\mathrm{Fe} / \mathrm{kg}$ and within the two groups fed $40 \mathrm{mg} / \mathrm{kg}$; in addition, a dose effect was looked for by comparison between the two $\mathrm{FeSO}_{4}$ groups and between the two $\beta$-CN (1-25) groups.

A probability level of $p<0.05$ was considered significant.

\section{RESULTS}

During the two last weeks of the study, total weight gains were $61 \pm 6$ and $81 \pm 7 \mathrm{~g}$ in $\mathrm{FeSO}_{4}$ and $\beta$-CN (1-25) $40 \mathrm{mg} \mathrm{Fe}$ fed groups, respectively $(t=2.0, p=$ 0.06); for $200 \mathrm{mg}$ groups weight gains were $92 \pm 5,93$ $\pm 4,106 \pm 4$, and $110 \pm 3 \mathrm{~g}$ in $\mathrm{FeSO}_{4}, \beta$-CN $(1-25)$, pair-fed, and Cas-Fe groups, respectively (ANOVA, $F$ $=5.3$; Fisher's exact t test, $p=0.005)$; a significant difference $\left(p<0.05\right.$ ) was displayed between $\mathrm{FeSO}_{4}$ or $\beta$-CN (1-25) and pair-fed or Cas-Fe groups; $\mathrm{FeSO}_{4}$ did not differ from $\beta$-CN (1-25) animals nor pair-fed from Cas-Fe.

Hemoglobin ( $\mathrm{Hb}$ ) levels and red blood cell counts (RBC) at the beginning and the end of repletion period are given in Table 2. Reticulocyte counts were not performed at the end of the repletion periods because they add no information to a normal RBC count. Because of a significant difference between $\mathrm{Hb}$ levels of experimental groups at the end of depletion, an ANOVA with repeated measures was performed to study the changes occurring during the two repletion weeks.

The weights ( $\mathrm{g} ; \mathrm{x} \pm \mathrm{SEM}$ ) of liver were $11.3 \pm 1.0$ and $15.9 \pm 1.4$, respectively, in $\mathrm{FeSO}_{4}$ and $\beta$-CN (125) (40 mg) animals (F isher's exact t test, $p<0.05$ ), and spleen weights were $0.9 \pm 0.1$ and $1.1 \pm 0.1$ (NS); liver weights of $\mathrm{FeSO}_{4}(200 \mathrm{mg})$ animals (14.1 \pm 0.7$), \beta$-CN $(1-25)(200 \mathrm{mg})(13.4 \pm 1.2)$, pair-fed (12.6 \pm 0.8$)$, and Cas-Fe (14.5 \pm 0.8$)$ did not significantly differ. The weights of spleen were $2.1 \pm 0.1\left[\mathrm{FeSO}_{4}(200 \mathrm{mg})\right], 0.6$ $\pm 0.0[\beta$-CN (1-25)(200 mg)], $1.2 \pm 0.1$ (pair-fed), and $1.1 \pm 0.1$ (Cas-Fe); these four groups were different (ANOVA, $\mathrm{p}<0.05): \mathrm{FeSO}_{4}(200 \mathrm{mg})$ was higher than the three other groups (Fisher's exact t test, $p<0.05$ ); $\beta$-CN (1-25) (200 mg) was lower than pair-fed and $\mathrm{FeSO}_{4}(200 \mathrm{mg})$ groups ( $\left.\mathrm{p}<0.05\right)$.

Because of the differences in the weight of organs, $\mathrm{Fe}$ concentrations of liver and spleen are shown in Figure 1 and their total content in Figure 2.

\section{DISCUSSION}

Digestive interactions between proteins and Fe are not fully defined: increased Fe dialyzability following in vivo digestion of various kinds of proteins appears to be more predictive of its absorption rate than its solubility (Hurrell et al., 1988; Kane and Miller, 1984; 
Table 2. Changes in Hemoglobin Concentration and Red Blood Cell Count (RBC) during Repletion of Weaning Rats (4

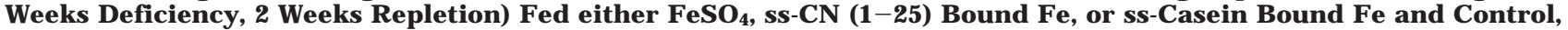
Nondeficient Rats

\begin{tabular}{|c|c|c|c|c|c|c|c|c|}
\hline & \multicolumn{4}{|c|}{ hemoglobin } & \multicolumn{4}{|c|}{ RBC } \\
\hline & $\begin{array}{l}\text { beginning of } \\
\text { repletion }\end{array}$ & $\begin{array}{l}\text { end of } \\
\text { repletion }\end{array}$ & change & $\begin{array}{l}\text { ANOVA, } \\
p<0.001\end{array}$ & $\begin{array}{l}\text { beginning of } \\
\text { repletion }\end{array}$ & $\begin{array}{l}\text { end of } \\
\text { repletion }\end{array}$ & change & $\begin{array}{l}\text { ANOVA, } \\
p<0.001\end{array}$ \\
\hline $\begin{array}{l}\mathrm{FeSO}_{4} \\
(1-25) \\
\text { ANOVA }\end{array}$ & $\begin{array}{l}5.7 \pm 0.8^{a} \\
5.3 \pm 0.1 \\
p=0.33\end{array}$ & $\begin{array}{l}11.9 \pm 1.6^{(A} \\
11.6 \pm 1.1 \\
p=0.71\end{array}$ & $\begin{array}{l}\text { e Supply du } \\
6.2 \pm 1.7 \\
6.3 \pm 1.2 \\
p=0.50\end{array}$ & $\begin{array}{l}\text { g Repletion } \\
p<0.05 \\
p<0.05\end{array}$ & $\begin{array}{l}40 \mathrm{mg} \text { of } \mathrm{Fe} / \mathrm{k} \\
3.39 \pm 0.11 \\
3.21 \pm 0.05 \\
\mathrm{p}=0.32\end{array}$ & $\begin{array}{l}\text { f Diet } \\
7.23 \pm 0.39 \\
6.74 \pm 0.18 \\
p=0.39\end{array}$ & $\begin{array}{l}3.84 \pm 1.24 \\
3.66 \pm 0.25 \\
p=0.56\end{array}$ & $\begin{array}{l}p<0.05 \\
p<0.05\end{array}$ \\
\hline $\begin{array}{l}\text { pair-fed } \\
\mathrm{FeSO}_{4} \\
(1-25) \\
\text { Cas-Fe } \\
\text { ANOVA }\end{array}$ & $\begin{array}{l}15.5 \pm 0.8^{a} \\
5.6 \pm 1.0^{a} \\
6.3 \pm 0.2^{a} \\
5.4 \pm 0.1^{a b} \\
p<0.001\end{array}$ & $\begin{array}{l}\quad(B) \\
15.1 \pm 1.0^{\mathrm{ab}} \\
13.2 \pm 0.9^{\mathrm{ab}} \\
15.1 \pm 0.3 \\
13.6 \pm 0.7^{\mathrm{ab}} \\
\mathrm{p}<0.001\end{array}$ & $\begin{array}{l}\text { e Supply dur } \\
-0.6 \pm 1.6 \\
7.6 \pm 0.9^{a b} \\
8.8 \pm 0.7^{a} \\
8.2 \pm 0.8^{a} \\
p<0.001\end{array}$ & $\begin{array}{l}\text { g Repletion } \\
\text { NS } \\
p<0.05 \\
p<0.05 \\
p<0.05\end{array}$ & $\begin{array}{l}200 \mathrm{mg} \text { of } \mathrm{Fe} / \mathrm{k} \\
7.07 \pm 0.25 \\
3.47 \pm 0.25^{\mathrm{a}} \\
3.77 \pm 0.13^{\mathrm{a}} \\
3.31 \pm 0.05^{\mathrm{a}} \\
\mathrm{p}<0.001\end{array}$ & $\begin{array}{l}\text { of Diet } \\
7.41 \pm 0.16 \\
6.23 \pm 0.15^{\mathrm{ac}} \\
6.50 \pm 0.05^{\mathrm{a}} \\
6.93 \pm 0.11^{\mathrm{b}} \\
p<0.001\end{array}$ & $\begin{array}{l}0.15 \pm 0.67 \\
2.75 \pm 0.47^{\mathrm{ac}} \\
2.72 \pm 0.30^{\mathrm{a}} \\
3.63 \pm 0.36^{\mathrm{ab}} \\
\mathrm{p}<0.001\end{array}$ & $\begin{array}{l}\text { NS } \\
p<0.05 \\
p<0.05 \\
p<0.05\end{array}$ \\
\hline
\end{tabular}

a Hemoglobin, $\mathrm{g} / \mathrm{dL} ; \mathrm{RBC}, 106 / \mathrm{mL} ; \mathrm{x} \pm \mathrm{SEM} ; \mathrm{n}=8 / \mathrm{group}$. Source of iron: $\mathrm{FeSO}_{4}, \mathrm{FeSO}_{4} \cdot 7 \mathrm{H}_{2} \mathrm{O} ;(1-25)$, $\mathrm{Fe}$ bound to $\beta$-CN (1-25) of $\beta$-casein; Cas-Fe, Fe bound to whole $\beta$-casein; pair-fed, nondeficient control rats pair-fed to experimental groups (6 weeks, $200 \mathrm{mg} / \mathrm{kg}$ $\mathrm{FeSO}_{4}$ ). Statistical analysis, ANOVA with repeated measures followed by Fisher's exact $t$ test: within rows, effect of time; within columns, differences between groups, Fisher's exact t test (a, vs pair-fed; b, vs 1-25 CPP; c, vs Cas-Fe; $p<0.05$ ).

a)

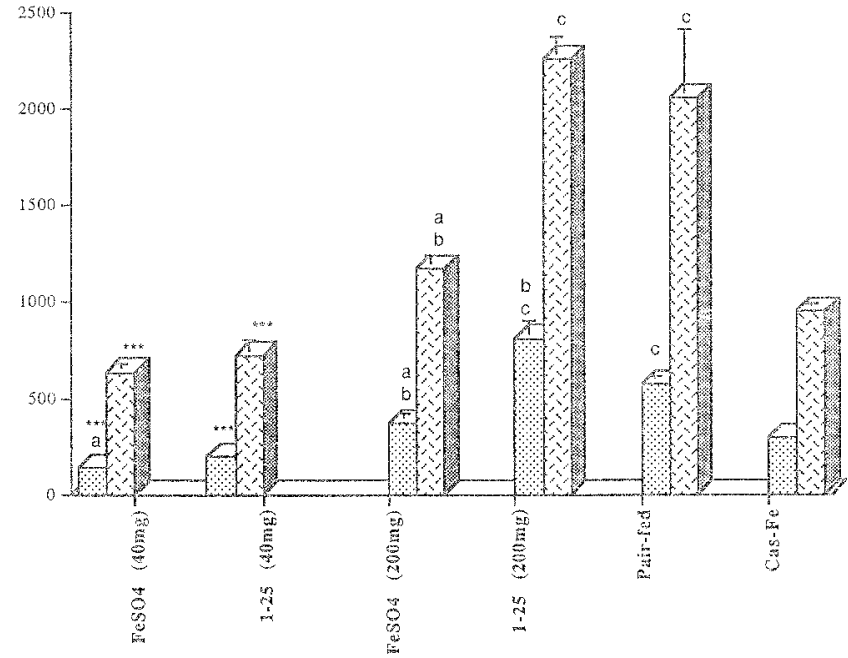

Figure 1. Liver and spleen Fe concentrations after repletion of Fe-deficient weaning rats (4 weeks deficiency, 2 weeks repletion) fed either $\mathrm{FeSO}_{4}$ or $\beta$-CN (1-25) bound $\mathrm{Fe}$ : (A) repletion with $40 \mathrm{mg}$ of $\mathrm{Fe} / \mathrm{kg}$ of diet; (B) repletion with 200 $\mathrm{mg}$ of $\mathrm{Fe} / \mathrm{kg}$ of diet; (dotted bars) liver iron $(\mu \mathrm{g} / \mathrm{g}$ ); (crosshatched bars) spleen iron $(\mu \mathrm{g} / \mathrm{g}) ;(*) \mu \mathrm{g} / \mathrm{g} ; \mathrm{x} \pm \mathrm{SEM} ; \mathrm{n}=8 / \mathrm{group}$. Source of iron: $\mathrm{FeSO}_{4}, \mathrm{FeSO} \cdot 7 \mathrm{H}_{2} \mathrm{O} ;(1-25)$, Fe bound to $\beta$-CN $(1-25)$ of $\beta$-casein; Cas-Fe, Fe bound to whole $\beta$-casein; pairfed, nondeficient control rats pair-fed to experimental groups (6 weeks, $200 \mathrm{mg} / \mathrm{kg} \mathrm{FeSO}$ ). Influence of the Fe source: (ANOVA followed by Fisher's exact t test) a, different $(p<0.05)$ from (1-25); b, different ( $p<0.05$ ) from pair-fed; c, different from Cas-Fe $(p<0.05)$. Liver: (A) ANOVA, $p=0.007$; (B) ANOVA, $p<0.001$. Spleen: (A) ANOVA, no difference between groups; (B) ANOVA, $p<0.001$. A vs B: (***) different from $200 \mathrm{mg}$ group fed the same form of Fe (Fisher's exact $t$ test; $p$ $<0.05$ ).

Kim et al., 1995; Miller and Berner, 1989); thus, a protecting effect of proteins does not rely only on their ability to keep Fe in a reduced and soluble form but depends also on the weight of the complexes that can be formed: high molecular weight proteins could be excluded from the brush border surface by the mucus, preventing access of Fe to membrane receptors (Miller and Berner, 1989).

The strong affinity of egg and milk phosphoproteins for divalent cations (Baumy and Brulé, 1988; Brulé and Fauquant, 1982; Hegenauer et al., 1979; West, 1986) is resistant to phosphatases (Bouhallab et al., 1991). When ingested in an intact form, these proteins are assumed
A)

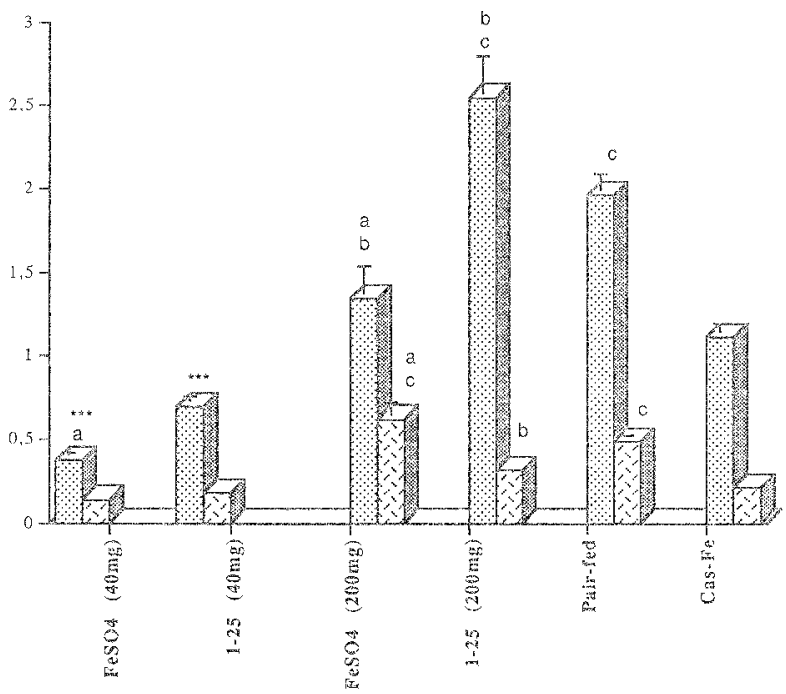

Figure 2. Fe total content of liver and spleen after repletion of Fe-deficient weaning rats (4 weeks deficiency, 2 weeks repletion) fed either $\mathrm{FeSO}_{4}$ or $\beta$-CN $(1-25)$ bound $\mathrm{Fe}$ : (A) repletion with $40 \mathrm{mg}$ of $\mathrm{Fe} / \mathrm{kg}$ of dietl (B) repletion with 200 $\mathrm{mg}$ of $\mathrm{Fe} / \mathrm{kg}$ of diet; (dotted bars) liver iron $(\mu \mathrm{g} / \mathrm{g}$ ); (crosshatched bars) spleen iron ( $\mu \mathrm{g} / \mathrm{g})$; (*) $\mathrm{mg}, \mathrm{x} \pm \mathrm{SEM}, \mathrm{n}=8 /$ group. Source of iron: $\mathrm{FeSO}_{4}, \mathrm{FeSO}_{4} \cdot 7 \mathrm{H}_{2} \mathrm{O} ;(1-25), \mathrm{Fe}$ bound to $\beta$-CN $(1-25)$ of $\beta$-casein; Cas-Fe, Fe bound to whole $\beta$-casein; pairfed, nondeficient control rats pair-fed to experimental groups (6 weeks, $200 \mathrm{mg} / \mathrm{kg} \mathrm{FeSO}$ ). Influence of the $\mathrm{Fe}$ source: (ANOVA followed by Fisher's exact t test) $a$, different $(p<0.05)$ from ( $1-25) ; b$, different $(p<0.05)$ from pair-fed; $c$, different from Cas-Fe $(p<0.05)$. Liver: (A) ANOVA, $p=0.001$; (B) ANOVA, $p<0.001$. Spleen: (A) ANOVA, no difference between groups; (B) ANOVA, $p<0.001$ A vs $B:(* * *)$ different from $200 \mathrm{mg}$ group fed the same form of Fe (Fisher's exact $t$ test; $p$ $<0.05$ ).

to decrease Fe bioavailability (Morris, 1983; Wapnir, 1990; West, 1986) yet they bind and keep it soluble at Iuminal pH (Baumy and Brulé, 1988; Galdi and Valencia, 1988; Hegenauer et al., 1979); hydrolyzing them into low molecular weight peptides prior to their ingestion improves Fe absorption, as previously shown in human studies (Hurrell et al., 1989).

The 25 amino acid phosphopeptide of $\beta$-casein $[\beta$-CN $(1-25)]$ forms soluble and steady complexes with $\mathrm{Fe}$ at luminal pH (Meisel and Frister, 1989; Bouhallab et al., 1991) and enhances Fe absorption by isolated duodenal loop (Pérès et al., 1997, 1998). 
The results of the present study support the good bioavailability of $\beta$-CN (1-25) bound Fe: it improved both $\mathrm{Fe}$ tissue storage and $\mathrm{Hb}$ levels during repletion of the deficient young rat, as compared to free $\mathrm{FeSO}_{4}$; Fe bound to the whole, nonhydrolyzed casein had a similar effect on $\mathrm{Hb}$ levels but was less efficient in improving tissue stores. Total liver Fe levels reflect the size of Fe stores such as ferritin Fe and are similarly depleted during Fe deficiency (Siimes et al., 1980; Dhur et al., 1989).

Improved Fe luminal solubility could have contributed to the availability of $\beta$-casein $\mathrm{Fe}$ to restore $\mathrm{Hb}$ levels; the better efficiency of $\beta$-CN (1-25) bound $\mathrm{Fe}$, which enhanced also $\mathrm{Fe}$ storage by organs, seems to support the hypothesis of a barrier effect of mucus against large peptides (Miller and Berner, 1989). The observation by Kasai et al. (1995) of a similar content of CPP in the ileum of rats fed either casein or CPP does not take into account the kinetics of protein hydrolysis that yields digestion products throughout the upper part of the digestive tract, whereas Fe absorption can occur only in the duodenum and proximal jejunum (Beard, 1996); therefore, it appears useful that Fe reaches the upper part of the bowel yet bound to low molecular weight ligands which could favor its absorption.

In addition, CPP-bound Fe could be absorbed though a different mechanism than inorganic Fe: part of $\beta$-CN (1-25) bound $\mathrm{Fe}$ is absorbed by endocytosis (Pérès et al., 1999); enterocytes are able to uptake large peptides, up to 30 kDa (Pantzar et al. 1993); uptake and plasma detection of biologically active peptides derived from caseins have also been consistently reported (Maubois and Léonil, 1989; Chabance et al., 1998). These facts support the assumption that at least part of $\beta$-CN (125 ) bound Fe could pass into the blood still in a bound form.

Supplying Fe in a bound form could al so influence its metabolism in the organism once absorbed and explain its improved tissue storage as compared to inorganic Fe: as shown for zinc, the presence of amino acids and peptides determines the metabol ism of trace elements, in addition to influencing their absorption. Adding milk proteins to a zinc-containing meal improves its absorption yet it decreases its serum level, suggesting an enhanced tissue clearance of absorbed metal (Sandström et al., 1980).

The deficient rat has been used extensively to evaluate the bioavailability of Fe compounds used or proposed for fortification of human food (Mahoney and Hendricks, 1984): it has a reduced sensitivity to dietary effects and cannot be used to quantify the influence of these factors in human nutrition (Reddy and Cook, 1991). However, the low sensitivity of this model suggests that differences in the efficiency of the two forms of Fe in restoring Fe stores and $\mathrm{Hb}$ levels which are displayed in the rat would still occur in humans; this should be demonstrated in further clinical studies.

\section{CONCLUSION}

Binding Fe to the 1-25 caseinophosphopeptide issued from the enzymatic hydrolysis of $\beta$-casein led to a better correction of anemia than $\mathrm{FeSO}_{4}$ and improved Fe stores better than $\mathrm{FeSO}_{4}$ and whole casein bound $\mathrm{Fe}$. The dietary source of CPP and the protecting effect against peroxidation of complexes of $\mathrm{Fe}$-bound phosphopeptides (Hegenauer et al., 1979) suggest they have a potential interest in food fortification.

\section{ABBREVIATIONS USED}

CPP, caseinophosphopeptides; $\beta$-CN (1-25), $1-25$ caseinophosphopeptide of $\beta$-casein; $\mathrm{FeSO}_{4} 40 \mathrm{mg}$ or $\mathrm{FeSO}_{4} 200 \mathrm{mg}$, animals repleted with $\mathrm{Fe}^{2+} \mathrm{SO}_{4}$ at a concentration of $40 \mathrm{mg}$ or $200 \mathrm{mg}$ of $\mathrm{Fe} / \mathrm{kg}$ of diet; $\beta$-CN (1-25) $40 \mathrm{mg}, \beta$-CN (1-25) $200 \mathrm{mg}$, animals repleted with $\beta$-CN (1-25) bound $\mathrm{Fe}$ at a concentration of $40 \mathrm{mg}$ or $200 \mathrm{mg}$ of $\mathrm{Fe} / \mathrm{kg}$ of diet; Cas-Fe $200 \mathrm{mg}$, animals repleted with $\beta$-casein bound $\mathrm{Fe}$ at a concentration of $200 \mathrm{mg}$ of $\mathrm{Fe} / \mathrm{kg}$ of diet.

\section{LITERATURE CITED}

Baumy, J . J .; Brulé, G. Effect of pH and ionic strength on the binding of bivalent cations to $\beta$-casein. Lait 1988, 68, 409418.

Beard, J . L.; Dawson, H.; Pinero, D. J . Iron metabolism: a comprehensive review. Nutr. Rev. 1996, 54, 295-317.

Berrocal, R.; Chanton, S.; J uillerat, M. A.; Pavillard, B.; Scherz, J . C.; J ost, R. Tryptic phosphopeptides from whole casein. II. Physicochemical properties related to the solubilization of calcium. J . Dairy Res. 1989, 56, 335-341.

Bouhallab, S.; Léonil, J .; Maubois, J . L. Complexation du fer par le phosphopeptide (1-25) de la caséine $\beta$ : action de I'alcalase et de la phosphatase acide. Lait 1991, 71, 435443.

Brulé, G.; Fauquant, J . Interaction des protéines du lait et des ol igo-éléments. Lait 1982, 62, 323-331.

Brulé, G.; Fauquant, J .; Maubois, J . L. Preparation of native phosphocaseinate by combining membrane ultrafiltration and ultracentrifugation. J . Dairy Sci. 1979, 62, 869-875.

Chabance, B.; Marteau, P.; Rambaud, P. C.; Migliore-Samour, D.; Boynard, M.; Perrotin, P.; Guillet, R.; J ollès, P.; Fiat, A. $M$. Casein peptide release and passage to the blood in humans during digestion of milk or yogurt. Biochimie 1998, 80, 155-165.

Cook, J. D.; Monsen, E. R. Food Fe absorption in human subjects. III. Comparison of the effect of animal proteins on non-heme Fe absorption. Am. J . Clin. Nutr. 1976, 29, 859867.

Demott, B. J .; Dincer, B. Binding added iron to various milk proteins. J. Dairy Sci. 1976, 59, 1557-1559.

Dhur, A.; Galan, P.; Hercberg, S. Effects of different degrees of iron deficiency on cytochrome P450 complex and pentose phosphate pathway dehydrogenases in the rat. J. Nutr. 1989, 119, 40-47.

Emery, T. Iron oxidation by casein. Biochem. Biophys. Res. Commun. 1992, 182, 1047-1052.

Galdi, M.; Valencia, M. E. Stability of iron (III) chelates of nutritional interest. J . Food Sci. 1988, 53, 1844-1847.

Hegenauer, J.; Saltman, P.; Ludwig, D.; Ripley, L.; Ley, A. Iron-supplemented cow milk. Identification and spectral properties of iron bound to casein micelles. J . Agric. Food Chem. 1979, 27, 1294-1301.

Hurrell, R. F.; Lynch, S. R.; Trinidad, T. P.; Dassenko, S. A.; Cook, J. D. Iron absorption in humans: bovine serum albumin compared with beef muscle and egg white. Am. J . Clin. Nutr. 1988, 47, 102-107.

Hurrell, R. F.; Lynch, S. R.; Trinidad, P.; Dassenko, S. A.; Cook, $J$ J. D. Fe absorption in humans as influenced by bovine milk proteins. Am. J. Clin. Nutr. 1989, 49, 546-552.

Hurrell, R. F.; J uillerat, M. A.; Reddy, M. B.; Lynch, S. R.; Dassenko, S. A.; Cook, J. D. Soy protein, phytate, and Fe absorption in humans. Am. J . Clin. Nutr. 1992, 56, 573578.

J uillerat, M. A.; Baechler, R.; Berrocal, R.; Chanton, S.; Scherz, J . C.; J ost, R. Tryptic phosphopeptides from whole casein. Preparation and analysis by fast protein liquid chromatography. J . Dairy Res. 1989, 56, 603-611.

Kane, A. P.; Miller, M. S. In vitro estimation of the effcts of selected proteins on iron bioavailability. Am. J . Clin. Nutr. 1984, 39, 393-401. 
Kasai, T.; I wasaki, R.; Tanaka, M.; Kiriyama, S. Caseinphosphopeptides (CPP) in feces and contents in digestive tract of rats fed casein and CPP fractions. Biosci., Biotechnol., Biochem. 1995, 59, 26-30.

Kim, M.; Lee, D. T.; Lee, Y. S. I ron absorption and intestinal solubility in rats are influenced by dietary proteins. Nutr. Res. 1995, 15, 1705-1716.

Mahoney, A. W.; Hendricks, D. G. Potential of the rat as a model for predicting iron bioavailability for humans. Nutr. Res. 1984, 4, 913-922.

Manson, W.; Annan, W. D. The structure of phosphopeptide derived from $\beta$ casein. Arch. Biochem. Biophys. 1971, 145, 16-26.

Martinez-Torres, C.; Romano, E.; Layrisse, M. Effect of cysteine on Fe absorption in man. Am. J . Clin. Nutr. 1981, 34, 322-327.

Maubois, J . L .; Léonil, J . Peptides du lait à activité biologique. Lait 1989, 69, 245-269.

Meisel, H.; Frister, H. Chemical characterization of bioactive peptides from in vivo digests of casein. J . Dairy Res. 1989, 56, 343-349.

Miller, D. D.; Berner, L. A. Is solubility in vitro a reliable predictor of iron bioavailability? Biol. TraceElem. Res. 1989, 19, 11-24.

Morris, E. R. An overview of current information on bioavailability of dietary iron to humans. Fed. Proc. 1983, 42, 17161720.

Naito, H.; Kawakami, A.; Imamura, T. In vivo formation of phospho-peptides with calcium binding properties in the small intestinal tract of the rat fed casein. Agric. Biol. Chem. 1972, 36, 409-415.

National Research Council, Sucommittee on Laboratory Animal Nutrition; Committee on Animal Nutrition-Board on Agriculture. Nutrient requirements of the Laboratory Rat. In Nutrient requirements of Laboratory Animals, 4th ed.; National Academy Press: Washington, DC, 1995.

Pantzar, N.; Weström, B. R.; Luts, A.; Lundin, S. Regional small-intestinal permeability in vitro to different-sized dextrans and proteins in the rat. Scand. J . Gastroenterol. 1993, 28, 205-211.
Pérès, J . M.; Bouhallab, S.; Bureau, F.; Maubois, J . L.; Arhan, P.; Bouglé, D. Absorption digestive du fer lié au caséinophosphopeptide (1-25) de la $\beta$ caséine. Lait 1997, 77, 433440.

Pérès, J . M.; Bouhallab, S.; Bureau, F .; Maubois, J . L.; Arhan, P.; Bouglé, D. Mechanisms of absorption of caseinophosphopeptide bound iron. J . Nutr. Biochem. 1999, 10, 215222.

Reddy, M. B.; Cook, J . D. Assessment of dietary determinants of nonheme-iron absorption in humans and rats. Am. J . Clin. Nutr. 1991, 54, 723-728.

Sandström, B.; Arvidsson, B.; Cederblad, A.; Björn-Rasmussen, $E$. Zinc absorption from composite meals $I$. The significance of wheat extraction rate, zinc, calcium, and protein content in meals based on bread. Am. J . Clin. Nutr. 1980, 33, 739745.

Sato, R.; Shindo, M.; Gunshin, H.; Noguchi, T.; Naito, H. Characterization of phosphopeptide derived from bovine $\beta$-casein: an inhibitor to intra-intestinal precipitation of calcium phosphate. Biochim. Biophys. Acta 1991, 1077, 413-415.

Siimes, M. A.; Refino, C.; Dallman, P. R. Manifestation of iron deficiency at various levels of dietary intake. Am. J . Clin. Nutr. 1980, 33, 570-574.

Thompson, D. B.; Erdman, J. W. The effect of soy protein isolate in the diet on retention by the rat of Fe from radiolabeled test meals. J . Nutr. 1984, 114, 307-311.

Wapnir, R. A. Chapter 6: Nutritional factors, proteins and the absorption of iron and cobalt. In Protein Nutrition and Mineral Absorption; Wapnir, R. A., Ed.; CRC Press: Boca Raton, FL, 1990; pp 99-129.

West, D. W. Structure and function of phosphorylated residues of casein. J . Dairy Res. 1986, 53, 333-352.

Received for review September 15, 1998. Revised manuscript received April 28, 1999. Accepted April 28, 1999. This study was partly supported by Diépal nsa, Groupe Danone.

J F 981018K 